\title{
СОФ'ÏH M.I.
}

\section{РОЛЬ І ЗНАЧЕННЯ ДІЯЛЬНОСТІ МІСЦЕВИХ ОРГАНІВ ВЛАДИ В РЕАЛІЗАЦІЇ ФІСКАЛЬНОЇ ПОЛІТИКИ В УКРАЇНІ}

У статті на основі аналізу норм чинного законодавства України та наукових поглядів вчених визначено та охарактеризовано роль і значення діяльності місцевих органів влади в реалізації фіскальної політики в Україні. Встановлено, що місцеві органи влади, на які чинним національним законодавством покладено обов'язок реалізації фіскальної політики в Україні, представлені двома групами - органами державної влади та органами місцевого самоврядування. Наголошено на тому, що особливу роль у реалізації фіскальної політики відіграють органи місцевого самоврядування, що зумовлено тим, що вони наділені повноваженнями зі встановлення місцевих податків і зборів. Окрім цього, місцеві органи влади забезпечують виконання ще низки завдань, пов'язаних із мобілізацією місцевих бюджетів, а також інших фондів грошових коштів. Серед місцевих органів державної влади можуть бути названі органи загальної та спеціальної компетенції. Як місцеві органи спеціаа інших центральних органів виконавчої влади. Роль і призначення таких органів у реалізації фіскальної політики в Україні буде збігатися з роллю та призначенням тих державних органів влади, відповідно до рішення яких вони були створені й завдання яких вони виконують у межах відповідної адміністративно-територіальної одиниці держави. Своєю чергою, як місцеві органи загальної компетенції, фіскальну політику в Україні реалізують місцеві державні адміністрації. Роль і призначення цих місцевих органів державної влади в реалізації фіскальної політики в межах відповідної адміністративно-територіальної одиниці країни зумовлені тим, що вони: здійснюють контрольну діяльність, зокрема в напрямі дотримання іншими суб' єктами фінансової дисципліни; здійснюють інформаційно-аналітичне забезпечення бюджетного процесу; взаємодіють з іншими місцевими суб'єктами 3 питань реалізації фіскальної політики в Україні.

Ключові слова: роль, значення, місиеві органи державної влади, фіскальна політика, реалізачія, органи місцевого самоврядування.

In the article, on the basis of analysis of the norms of the current legislation of Ukraine and the scientific views of scientists, the role and significance of the activities of local authorities in the implementation of fiscal policy in Ukraine is determined and characterized. It has been established that local authorities, in which the current national legislation imposes the obligation to implement fiscal policy in Ukraine, are represented by two groups - state authorities and local self-government bodies. It was emphasized that local governments play a special role in the implementation of fiscal policy, due to the fact that they have the authority to set local taxes and fees. In addition, these local authorities provide a number of tasks related to the mobilization of local budgets as well as other funds. It is concluded that local authorities, under which the current national legislation imposes the duty to implement fiscal policy in Ukraine, are represented by two groups - state authorities and local self-government bodies. Local and special authorities may be designated as local authorities. As local authorities of special competence, we have considered the territorial entities (bodies) of ministries and other central executive bodies. The role and designation of such bodies in the implementation of fiscal policy in Ukraine will coincide with the role and designation of those public authorities, according to the decisions of which they were created and whose tasks they fulfill within the respective administrative and territorial unit of the state. In

(C) СОФ'ÏН М.I. - кандидат юридичних наук, докторант (Науково-дослідний інститут публічного права) 
turn, as local authorities of general competence, fiscal policy in Ukraine is implemented by local state administrations. The role and designation of data of local authorities in the implementation of fiscal policy within the respective administrative and territorial unit of the country is conditioned by the fact that they: carry out control activities, in particular in the direction of compliance with other subjects of financial discipline; carry out information and analytical support of the budget process; interact with other local entities on fiscal policy implementation in Ukraine.

Key words: role, significance, local authorities, fiscal policy, implementation, bodies of local self-government.

Вступ. Реалізація фіскальної політики в Україні здійснюється не тільки суб’єктами, які діють у межах держави загалом. Провідну роль у реалізації такої політики відіграють також місцеві органи влади, які діють у межах окремо взятої адміністративно-територіальної одиниці нашої держави. 3 огляду на те, що останнім часом активнішими стають процеси, пов'язані $з$ децентралізацією влади, особливого значення набувають питання з визначення ролі місцевих органів влади в реалізації фіскальної політики в Україні. Адже саме від того, наскільки вдало буде реалізовано фіскальну політику на цьому рівні, залежить ефективність її реалізації в межах всієї країни.

Окремі проблемні питання, щодо діяльності різних органів державної влади у сфері реалізації фіскальної політики в наукових працях розглядали С.М. Мошович, Л.Е. Соколовский, Н.В. Дацій, В.М. Мельник, В.М. Опарін, М.М. Фельдгольц, І.І. Вініченко, А.Л. Бикова, А.В Лобза, О.В. Гончаренко, С.О. Корецько, Т.Ю. Александрюк та багато інших. Однак, незважаючи на чималу кількість наукових розробок, в юридичній науці відсутнє єдине комплексне дослідження, присвячене діяльності місцевих органів влади в окресленій сфері суспільних відносин.

Постановка завдання. Метою статті є визначення ролі і значення діяльності місцевих органів влади в реалізації фіскальної політики в Україні

Результати дослідження. Досліджуючи роль і значення діяльності місцевих органів влади в реалізації фіскальної політики в Україні, варто мати на увазі, що ці органи можуть бути поділені на дві групи - місцеві органи державної влади й органи місцевого самоврядування. Так, говорячи про місцеві органи державної влади, варто вказати на те, що в Україні вони представлені органами загальної та спеціальної компетенції, які діють у межах відповідних адміністративно-територіальних одиниць. До місцевих органів державної влади загальної компетенції належать місцеві державні адміністрації. Своєю чергою, до місцевих органів виконавчої влади спеціальної компетенції належать органи, які безпосередньо підпорядковані міністерствам та іншим центральним органам виконавчої влади [1, с.734]. Як слідує з аналізу положень чинного національного законодавства, центральні органи виконавчої влади в межах окремо взятої адміністративно-територіальної одиниці здійснюють свої державно-владні повноваження через відповідні територіальні органи. Правовий статус територіальних органів центральних органів виконавчої влади визначено також на рівні Типового положення «Про територіальні органи міністерства та іншого центрального органу виконавчої влади», що затверджене Постановою Кабінету Міністрів України від 25 травня 2011 р. № 563. Як свідчить аналіз положень вищенаведеного нормативно-правового акта, завданням територіальних органів $є$ реалізація повноважень міністерства та іншого центрального органу виконавчої влади на території відповідної адміністративно-територіальної одиниці [2]. Тобто, розглядаючи правовий статус територіальних органів як місцевих органів влади, які реалізують фіскальну політику в Україні, варто зазначити, що їх роль і значення будуть зумовлені роллю і значенням діяльності тих міністерств та інших центральних органів виконавчої влади, відповідно до рішення яких вони були створені й завдання яких вони виконують у межах відповідної адміністративно-територіальної одиниці держави.

Іншими представниками місцевих органів державної влади є органи загальної компетенції, які представлені місцевими державними адміністраціями, які наділені широким колом повноважень, що свідчить про їхній особливий правовий статус як місцевого органу влади. Так, правовий статус дцих місцевих органів влади закріплено в Основному Законі України. Зокрема, в ст. 118 вищенаведеного нормативно-правового акта встановлено, що виконавчу владу в областях і районах, містах Києві та Севастополі здійснюють місцеві державні адміністрації. При цьому місцеві державні адміністрації на відповідній території забезпечують: виконання Конституції та законів України, актів Президента України, Кабінету Міністрів України, інших органів виконавчої влади; законність і правопорядок; додержання прав і свобод громадян; виконання державних і регіональних програм соціально-економічного та культурного розвитку, програм охорони 
довкілля, а в місцях компактного проживання корінних народів і національних меншин - також програм їхнього національно-культурного розвитку; підготовку та виконання відповідних обласних і районних бюджетів; звіт про виконання відповідних бюджетів і програм; взаємодію 3 органами місцевого самоврядування; реалізацію інших наданих державою, а також делегованих відповідними радами повноважень [3]. Більш детально правовий статус, організацію, повноваження та порядок діяльності місцевих державних адміністрацій визначено в положеннях Закону України «Про місцеві державні адміністрації» від 9 квітня 1999 р. Як зазначено в положеннях вищенаведеного нормативно-правового акта, місцева державна адміністрація є місцевим органом виконавчої влади і входить до системи органів виконавчої влади. Місцева державна адміністрація в межах своїх повноважень здійснює виконавчу владу на території відповідної адміністративно-територіальної одиниці, а також реалізує повноваження, делеговані їй відповідною радою [4].

Аналіз законодавчих положень, що визначають правовий статус місцевої державної адміністрації, свідчить про те, що цей орган місцевої влади наділений значним обсягом повноважень у сфері реалізації фіскальної політики держави. 3 огляду на значну кількість таких повноважень їх доцільно розглядати з урахуванням напряму їх здійснення. Окремим напрямом варто вважати здійснення контрольної діяльності. Підкреслюючи значення контрольної діяльності, науковці наголошують на тому, що вона є одним із найдієвіших засобів забезпечення законності в межах відповідних суспільних відносин [5, с. 102, 104]. Так, аналіз ст. 16 Закону України «Про місцеві державні адміністрації» свідчить, що місцеві державні адміністрації в межах реалізації фіскальної політики здійснюють контроль за станом фінансової дисципліни, обліку та звітності, виконанням державних контрактів і зобов'язань перед бюджетом, належним і своєчасним відшкодуванням шкоди, заподіяної державі [4].

У цьому контексті варто підкреслити, що контроль за дотриманням відповідними суб'єктами фінансової дисципліни є одним із найдієвіших заходів належної реалізації фіскальної політики, підтримання стану законності в цій сфері суспільних відносин. Адже, як зауважує авторський колектив, фінансова дисципліна - це чітке дотримання встановлених приписів і порядку утворення, розподілу та використання грошових фондів держави, суб'єктів місцевого самоврядування, підприємств, організацій, установ [6, с. 68]. Тому, здійснюючи контроль за дотриманням фінансової дисципліни, місцеві державні адміністрації в межах відповідної адміністративно-територіальної одиниці держави вчиняють вплив на реалізацію фіскальної політики шляхом забезпечення неухильного виконання всіма суб'єктами цих правовідносин приписів чинного законодавства щодо мобілізації, розподілу та використання фондів коштів, а також недопущення проявів неправовірної поведінки під час здійснення фінансової діяльності загалом.

Досліджуючи роль і значення діяльності місцевих державних адміністрацій у реалізації фіскальної політики в Україні, варто зазначити, що законодавець визначає особливості здійснення повноважень цими місцевими органами влади щодо окремо взятої групи суспільних відносин. Так, зазначені групи суспільних відносин, а також повноваження місцевих державних адміністрацій наведено в Розділі III «Компетенція місцевих державних адміністрацій» Главі 2 «Основні галузеві повноваження місцевих державних адміністрацій» [7]. Аналіз зазначених законодавчих приписів дає змогу назвати десять груп відповідних суспільних відносин, у межах яких місцеві державні адміністрації реалізують надані їм законодавцем повноваження на відповідній адміністративно-територіальній одиниці країни. У контексті досліджуваного питання найбільший для нас інтерес становлять повноваження місцевих державних адміністрацій у галузі бюджету та фінансів: «складає, схвалює та подає на розгляд ради прогноз відповідного бюджету, складає та подає на затвердження ради проект відповідного бюджету та забезпечує його виконання; звітує перед відповідною радою про його виконання; подає в установленому порядку до органів виконавчої влади вищого рівня фінансові показники та пропозиції до проекту Державного бюджету України, пропозиції щодо обсягу коштів Державного бюджету України для їх розподілу між територіальними громадами, розмірів дотацій і субсидій, дані про зміни складу об'єктів, що підлягають бюджетному фінансуванню, баланс фінансових ресурсів для врахування їх при визначенні розмірів субвенцій, а також для бюджетного вирівнювання виходячи із забезпеченості мінімальних соціальних потреб; отримує від усіх суб'єктів підприємницької діяльності незалежно від форм власності інформацію, передбачену актами законодавства для складання і виконання бюджету» [4]. Наявність таких повноважень характеризує місцеві державні адміністрації як одного з учасників бюджетного процесу, що здійснює його інформаційно-аналітичне забезпечення.

3 огляду на наведене місцеві державні адміністрації як суб'єкти реалізації фіскальної політики здійснюють контрольні повноваження щодо дотримання відповідними особами фі- 
нансової дисципліни в межах окремо взятої адміністративно-територіальної одиниці держави. Також місцеві державні адміністрації реалізуючи фіскальну політику держави здійснюють діяльність, спрямовану на інформаційно-аналітичне забезпечення бюджетного процесу. Особливістю правового статусу місцевих державних адміністрацій як суб'єктів реалізації фіскальної політики $€$ їх подвійне підпорядкування. 3 одного боку, вони підпорядковані вищим стосовно них органам виконавчої влади, з іншого - в частині реалізації ними делегованих повноважень вони підконтрольні органам місцевого самоврядування. При цьому варто наголосити на тому, що місцеві державні адміністрації вступають у відносини із взаємодії з органами місцевого самоврядування за значною кількістю питань, пов'язаних із реалізацією фіскальної політики в Україні. Саме тому наступним місцевим органом влади, який здійснює діяльність із реалізації фіскальної політики в межах відповідної адміністративно-територіальної одиниці держави, варто розглядати органи місцевого самоврядування.

Провідна роль органів місцевого самоврядування в реалізації фіскальної політики зумовлена тим, що саме дані органи місцевої влади наділені повноваженнями щодо встановлення місцевих податків і зборів. Такі повноваження цих суб' єктів реалізації фіскальної політики в Україні закріплено в ч. 1 ст. 143 Конституції України [3], а також в п. 24 ч. 1 ст. 26 Закону України «Про місцеве самоврядування в Україні» [7]. Як цілком слушно зауважують із цього приводу, місцеві податки та збори є одним із дієвих механізмів формування ресурсного потенціалу органів місцевого самоврядування, а також джерелом соціального та економічного розвитку територій громад. При цьому, оскільки запровадження місцевих податків і зборів та встановлення розміру їх ставок належить виключно до компетенції органів місцевого самоврядування, вони мають реальну змогу впливати на обсяги надходжень зазначених платежів до відповідних бюджетів. Отже, формування значної частини власних доходів місцевих бюджетів перебувають у прямій залежності від того, наскільки ефективно органи місцевого самоврядування зможуть організувати весь комплекс робіт із запровадження та мобілізації місцевих податків і зборів [8].

У цьому контексті варто зазначити, що правова регламентація суспільних відносин у сфері справляння податків і зборів здійснюється положеннями Податкового кодексу України від 2 грудня 2010 р. Як свідчить аналіз ст. 10 вищенаведеного нормативно-правового акта, до місцевих податків належать податок на майно й єдиний податок. Своєю чергою, до місцевих зборів належать збір за місця для паркування транспортних засобів, а також туристичний збір. При цьому сільські, селищні, міські ради та ради об'єднаних територіальних громад, що створені згідно із законом та перспективним планом формування територій громад, у межах своїх повноважень приймають рішення про встановлення місцевих податків та зборів [9]. 3 наведеного слідує, що здійснення органами місцевого самоврядування повноважень щодо встановлення місцевих податків і зборів характеризує їх як провідних місцевих органів влади, що відповідальні за реалізацію фіскальної політики в Україні. Реалізуючи зазначений напрям діяльності, органи місцевого самоврядування забезпечують мобілізацію коштів, необхідних для наповнення місцевих бюджетів, що має першорядне значення для розвитку відповідної адміністративно-територіальної одиниці, а отже, держави загалом.

Окрім цього, органи місцевого самоврядування в межах реалізації фіскальної політики в Україні здійснюють ще низку повноважень, пов'язаних із формуванням та використанням місцевих бюджетів, інших грошових фондів коштів, необхідних для функціонування та розвитку відповідної адміністративно-територіальної одиниці. Зокрема, як свідчить аналіз приписів ст. 28 Закону України «Про місцеве самоврядування в Україні», до цієї групи повноважень органів місцевого самоврядування варто зарахувати такі: затвердження програм економічного розвитку відповідних адміністративно-територіальних одиниць, цільових програм з інших питань; розгляд прогнозу місцевого бюджету, затвердження місцевого бюджету, внесення змін до місцевого бюджету; прийняття рішень щодо здійснення місцевих запозичень; прийняття рішень щодо передачі коштів з відповідного місцевого бюджету; прийняття рішень щодо надання відповідно до чинного законодавства пільг по місцевих податках і зборах, а також земельному податку; встановлення для підприємств, установ та організацій, що належать до комунальної власності відповідних територіальних громад, розміру частки прибутку, яка підлягає зарахуванню до місцевого бюджету; затвердження ставок земельного податку [7] тощо.

Аналіз положень чинного національного законодавства, на рівні якого закріплено правовий статус органів місцевого самоврядування, дає змогу назвати ще низку напрямів їх діяльності, пов'язаних із реалізацією фіскальної політики в Україні:

1) формування в межах відповідної адміністративно-територіальної одиниці інших суб'єктів реалізації фіскальної політики, що здійснюється шляхом реалізації таких повноважень: 
утворення та ліквідація постійних та інших комісій ради, затвердження та зміна їх складу, обрання голів комісій; утворення виконавчого комітету ради, визначення його чисельності, затвердження персонального складу; внесення змін до складу виконавчого комітету та його розпуск; затвердження за пропозицією сільського, селищного, міського голови структури виконавчих органів ради, загальної чисельності апарату ради та їі виконавчих органів; утворення за поданням сільського, селищного, міського голови інших виконавчих органів ради; створення в разі необхідності органів і служб для забезпечення здійснення з іншими суб'єктами комунальної власності спільних проектів або спільного фінансування (утримання) комунальних підприємств, установ та організацій, визначення повноважень цих органів (служб); прийняття рішення про дострокове припинення повноважень органів територіальної самоорганізації населення; затвердження статуту територіальної громади;

2) здійснення контрольної діяльності: заслуховування звіту сільського, селищного, міського голови про діяльність виконавчих органів ради, в тому числі щорічного звіту про здійснення державної регуляторної політики виконавчими органами відповідної ради; прийняття рішення про недовіру сільському, селищному, міському голові; заслуховування звітів постійних комісій, керівників виконавчих органів ради та посадових осіб, яких вона призначає або затверджує; заслуховування повідомлень депутатів про роботу в раді, виконання ними доручень ради; розгляд запитів депутатів, прийняття рішень по запитах; заслуховування звітів, пов'язаних із здійсненням відповідно до Закону України «Про співробітництво територіальних громад» [10] співробітництва територіальних громад, суб'єктом якого є територіальна громада села, селища, міста; заслуховування інформації прокурорів та керівників органів Національної поліції про стан законності, боротьби із злочинністю, охорони громадського порядку та результати діяльності на відповідній території [7].

Висновки. Таким чином, місцеві органи влади, на які чинним національним законодавством покладено обов'язок реалізації фіскальної політики в Україні, представлені двома групами - органами державної влади та органами місцевого самоврядування. Серед місцевих органів державної влади можуть бути названі органи загальної та спеціальної компетенції. Як місцеві органи спеціальної компетенції нами розглянуто територіальні утворення (органи) міністерств та інших центральних органів виконавчої влади. Роль і призначення таких органів у реалізації фіскальної політики в Україні буде збігатися з роллю та призначенням тих державних органів влади, відповідно до рішення яких вони були створені й завдання яких вони виконують у межах відповідної адміністративно-територіальної одиниці держави. Своєю чергою, як місцеві органи загальної компетенції фіскальну політику в Україні реалізують місцеві державні адміністрації. Роль і призначення цих місцевих органів державної влади в реалізації фіскальної політики в межах відповідної адміністративно-територіальної одиниці країни зумовлена тим, що вони: здійснюють контрольну діяльність, зокрема в напрямі дотримання іншими суб'єктами фінансової дисципліни; здійснюють інформаційно-аналітичне забезпечення бюджетного процесу; взаємодіють з іншими місцевими суб'єктами з питань реалізації фіскальної політики в Україні. Особливу роль у реалізації фіскальної політики відіграють органи місцевого самоврядування, що зумовлено тим, що вони наділені повноваженнями зі встановлення місцевих податків і зборів. Окрім цього, місцеві органи влади забезпечують виконання ще низки завдань, пов'язаних із мобілізацією місцевих бюджетів, а також інших фондів грошових коштів. Також органи місцевого самоврядування, реалізуючи фіскальну політику, формують інших суб'єктів цих правовідносин, а також здійснюють контрольні повноваження.

\section{Список використаних джерел:}

1. Юридична енциклопедія : в 6 т. / за ред. Ю.С. Шемшученка. Київ : «Українська енциклопедія» ім. М.П. Бажана, 1998-2004. Т. 3. К-М. 2001. 792 с.

2. Про затвердження Типового положення про територіальні органи міністерства та іншого центрального органу виконавчої влади : Постанова Кабінету Міністрів України від 25.05.2011 р. № 563. Офіиійний вісник України. 2011. № 41. Ст. 1677.

3. Конституція України : Закон України від 28.06.1996 p. № 254к/96 ВР. Відомості Верховної Ради України. 1996. № 30. Ст. 141.

4. Про місцеве державні адміністрації : Закон України від 09.04.1999 р. № 586-XIV. Bidoмості Верховної Ради України. 1999. № 20-21. Ст. 190.

5. Пчелін В.Б. Перегляд адміністративних актів органів внутрішніх справ у порядку контролю. Право і безпека. 2010. № 4 (36). С. 101-105. 
6. Нагребельний В.П., Чернадчук В.Д., Сухонос В.В. Фінансове право України. Загальна частина: Навчальний посібник / За заг. ред. члена-кореспондента АПрН України В.П. Нагребельного. Київ, 2003. 213 с.

7. Про місцеве самоврядування в України : Закон України від 21.05.1997 р. № 280/97-ВР. Відомості Верховної Ради України. 1997. № 24. Ст. 170.

8. Місцеві податки та збори. Центральний офіс реформ при Мінрегіоні. URL: https://storage. decentralization.gov.ua/uploads/library/file/261/Буклет_-_Місцеві_податки_перегляд__1_.pdf (дата звернення: 11.03.2019).

9. Податковий кодекс України : Закон України від 02.12.2010 p. № 2755-VI. Biдомості Верховної Ради Украӥни. 2011. № 13-14. № 15-16, № 17. Ст. 112.

10. Про співробітництво територіальних громад : Закон України від 17.06.2014 p. № 1508-VII. Відомості Верховної Ради Украӥни. 2014. № 34. Ст. 1167.

УДК 341:004+342.9

DOI https://doi.org/10.32844/2618-1258.2019.4-2.39

ТАРАСЮК А.В.

\section{ДОСВІД ЗАБЕЗПЕЧЕННЯ КІБЕРБЕЗПЕКИ В ЗАРУБІЖНИХ КРАЇНАХ}

Мета статті - аналіз найбільш складних і актуальних проблем забезпечення кібербезпеки в країнах СС і формування єдиної політики в цій сфері. Розглянуто загальні політичні та економічні чинники актуалізації проблем кібербезпеки на національному, наднаціональному та глобальному рівнях. На прикладі Румунії та Польщі проілюстровано становлення системи кіберзахисту в країнах Східної Свропи. На прикладі Німеччини та Фінляндії показано, що політика у сфері забезпечення кібербезпеки у низці розвинених країн ЄС більш ефективна, ніж політика на наднаціональному загальноєвропейському рівні. Зроблено висновок, що відмінною рисою німецького підходу до забезпечення кібербезпеки $є$ його комплексний $і$ фундаментальний характер, який включає цілу систему нормативних актів, планів й інститутів. Виявлено основні підходи й тенденції, пов'язані $з$ виробленням на наднаціональному рівні ЄС єдиної стратегії в області кібербезпеки. Встановлено, що основна проблема ефективного забезпечення кібербезпеки полягає у створенні в $Є С$ єдиного європейського політичного простору. Значна активність у цій сфері керівних органів ЄС стикається з нездатністю низки країн в повному обсязі виконати всі директиви, розпорядження, регламенти та інші нормативні акти. Через складні процедури узгодження на національному і наднаціональному рівнях, що вимагає значного часу, а також через несформованість в ЄС єдиного політичного простору держави і наднаціональні структури СС не завжди встигають вчасно реагувати на появу нових кіберзагроз. Проте, незважаючи на ці проблеми, система забезпечення кібербезпеки в країнах ЄС досить швидко розвивається і вдосконалюється, чому сприяє настільки ж швидке накопичення досвіду регулювання і координації дій країн - членів ЄС у сфері кібербезпеки. За результатами дослідження визначено, що в умовах розробки нашою державою національного законодавства у сфері кібернетичної безпеки (з урахування умов Угоди про асоціацію між Україною та (C) для України за умови відповідного корегування може бути корисним досвід $Є С$ щодо визначення або створення єдиного державного органу з питань кіберзахисту, здатного відповідати на кібератаки, сертифікації цифрових продуктів і послуг, заходи із захисту персональних даних користувачів комп'ютерних мереж, що передбачають значні штрафи за незаконне використання цих даних.

Ключові слова: кібербезпека, СС, загрози, кіберпростір, інформачія, дані.

(C) ТАРАСЮК А.В. - кандидат юридичних наук, головний науковий співробітник Наукової лабораторії забезпечення інформаційної та кібернетичної безпеки (Науково-дослідний інститут інформатики і права Національної академії правових наук України) 